\title{
The Election of Head of Village In the Perspective of System (A Case Study in the Election of Head of Neglasari Village of 2015)
}

\author{
Utang Suwaryo \\ Department of Government Science \\ Padjadjaran University \\ Bandung, Indonesia \\ Iyep Saefulrahman \\ Department of Government Science \\ Padjadjaran University \\ Bandung, Indonesia
}

\begin{abstract}
As a law community unit, village has power to manage and arrange its own affairs, among others, elects its leader called head of village. In the perspective of system, the election of head of village is built and moved by several sub-systems. The linkage between the sub-systems is interesting to be studied since any change in one subsystem will affect other sub-systems and the whole system. The study is more interesting since in the case of head of Neglasari village, the village tradition is still prevailed. The research is conducted to analyze the linkage between sub-systems and the work of village tradition in the election of head of Neglasari Village in 2015. Due to the purpose, the research approach used is qualitative research. Data is collected though interview, documentation and observation. Research result shows that in the election of head of Neglasari Village the sub-systems could work and support each other. It can be seen from the election that in accordance with state regulation thus the electoral process as well as resolution of any post-election disputes are worked well. Village tradition that is still ongoing gives color and meaning in the election of head of Neglasari Village in 2015 . Therefore, the state needs to give a chance to the village tradition to work along with the state regulation.
\end{abstract}

Keywords: Village, election of head of village, perspective of system

\section{INTRODUCTION}

Every individual lives with their own interest. In order to fulfill the interest, they would do anything including things that harm others. In their development along with their rationality ability, there are individuals who realized that the condition is no longer tolerated. Every human has the same purpose of life and it will need peace between human to achieve it. It is where a person with the ability to unite various interests of each individual is needed. That person should have the ability to influence others to act and behave according to their wish (the creation of peace). In political, government, and sociological term and other social studies, someone with those abilities is called a leader; whereas, his/her ability in influencing others is called leadership.

When a leader has been chosen in a group of individual and rules are set and implemented, it is an indication of a simple government. It can be stated that the birth of a leader among 
individuals is the beginning of the formation of a government. Therefore, leader and government cannot be separated.

In the context of village, leader refers to the head of village. Regardless the collegial governmental system, the head of village remains a central figure in village governance since the establishment of law community unit (village). It means that many heads of village are manifested in the village elders (sesepuh); however, there should be someone who will be a figure trusted by all villagers who could bring the village to a better direction and able to unify all differences through his/her act.

Antlov (2003) describes a leader or the village elder (sesepuh) in village governance. According to him, head of village is a figure expected by the people to become village representative in maintaining harmony between villages and the outside world and protect the people from outside influences. He/she is also expected to give paragon through attitude and manners. The point is that a leader should have moral credibility and social bond in the community he/she served. A leader will gain authority through support from the bottom, the ability to create social order and having spiritual stamina.

With this position and role, it is not easy to look and select a people leader (head of village). Regardless the difficulty, each village has their own "cara (way)" in choosing their leader that generally based on their own habit and customs. However, along with current development and intervention of supra power of the village, the village's "way" has been shifted by "tata (system)" (law or act) issued by the state through its policies. It is also experienced by Neglasari Village that located in Selawu Subdistrict, Tasikmalaya Regency. A "way" of Neglasari Village in choosing its leader is still prevailed despite the "system" of state as the formal rule in electing head of village.

At present, the arrangement of village is based on Act No. 6, 2014 on Village. The act states that head of village is elected by villagers and the election is conducted simultaneously. This simultaneous election regulation is a new thing for head of village election for Neglasari Village as well as all law community units in Indonesia.

Neglrasari Village is a village located at Salawu Subdistrict Tasikmalaya Regency West Java. Along with other 67 villages in Tasikmalaya, Neglasari gained an opportunity to have head of village election simultaneously in the first term in 2015. Refer to the end term of previous head of village, the election is conducted in 2014; however, due to state regulation, the election at Neglasari Village is postdated to March, 2015. The voting process is set on Monday, March 16, 2016.

In the perspective of system, the simultaneous regulation is one of components (sub-system) in the system of head of village election. The election of head of village itself is a sub-system for village government system. Therefore, a change in one of the components will affect the implementation of the election of head of village, specifically and the village government, generally. The change of the implementation of village government is indicated with the delays in the schedule of the election of head of Neglasari Village. In addition, the change also affects the governance structure of Neglasari Village with a vacancy in the position of village secretary since he/she became a caretaker of head of village. 
The paper will not discuss on the effect of the implementation of Act No. 6, 2014 at Neglasari in a whole. The focus of the research is in the implementation of the election of head of village using perspective of system for the discussion. Therefore, the purpose of the study is to analyze the linkage between sub-systems and the work of village tradition in the election of head of village at Neglasari in 2015.

\section{FRAMEWORK}

Village is a law partnership or unit of a community residence with authority to do their own government (Boeke, 1971; Kartohadikoesoemo, 1984). Due to its position, a village possesses not only its authority but also area and wealth or income. Those three characteristics are the basic for village governance and sourced from customs. One form of village governance is village democracy especially in the election of its leader (head of village). ${ }^{1}$

In the context of Indonesia, village democracy is the real democracy. B.J Haga as cited by Poerbopranoto (1978) stated that the life of indigenous people in Indonesia, such as nagari, desa, marga and others has their own "way" in democracy called "eastern democracy". Moh. Hatta (2009) also stated that village democracy is the real democracy that continues to develop, grow and live as a custom. It is based on actions by mutual consent. It means that village democracy is a common situation that occurs and lives in the village as a community unit who lives together.

The above explanation is in line with a statement by Wignjodipoero (1982) when viewing a village as a law community unit. There are three traditional atmosphere of a village due to its position. One of the atmospheres is a democracy that is in harmony with other atmospheres of religious and communal. The harmony builds a relationship which requires common interest above the personal interest. In this case, an individual, as part of a law community unit (custom), is bond to the society in their action. Democratic atmosphere created in law community unit is indicated and imbued by customs that have universal value. The basic of general power in law community unit is mutual consent and the system of government is consultative and representative.

The basic idea of village democracy according to Prijono Tjiptoherijanto and Yumiko M. Priyono (1983) is the present of people participation in the decision making through consultation (musawarah) process. According to them, it is this participation that becomes the basic of Moh. Hatta's opinion stating that musyawarah is the symbol of traditional democracy pattern along with gotong royong (mutual assistance) of its implementation in the village. Hofsteede as cited Priyono Tjiptoherijanto and Yumiko M. Priyono (1983) also explained that in Javanese tradition, customs arrange rural communities in the election of the head of village as well as village meeting, which is the highest authority of decision making in the village.

In the village governance, the election of head of village is an important sub-system of a system. Along with other sub-systems, such as tradition and customs, village elders, local institutions, and village internal affairs, it will interact and depend on each other to achieve village goals in governing and achieving public welfare. It is in accordance with David Easton's opinion explaining that system has at least three characters consist of many parts that interact and depend on each other and have border that separate it from its environment that also consists

\footnotetext{
${ }^{1}$ Koentjaraningrat (1990) explains that village democracy refers to decision making. In this case, the decision includes the election of head of village.
} 
other systems. ${ }^{2}$ Similar opinion also stated by Share and Voich who gave limitation to a system as "A set of interrelated parts, working independently and jointly, in pursuit of common objectives of the whoe, within a complex environment".3

Generally, the system has 4 (four) elements: input, process, output and feedback. In the context of the election of head of village, the four elements of the system can be explained as follow ${ }^{4}$ :

1. Input consists of voters, candidates of head of village, legislations on the election of head of village, supporting facilities and infrastructures, cost of election and village customs

2. Process consists of the selection of prospective candidates, the election (voting), and the determination of elected candidates who has the most votes.

3. Output consists of elected head of village who has been approved, appointed and inaugurated by authorities.

4. Feedback is related to the resolution of dispute in the election of head of village

In addition to those four elements, the system of the election of head of village has other parts called by Prihatmoko (2005) as secondary system or sub sub-system. Those parts encompass three things: electoral regulation that related to all rules or provisions prevailed as guidance in the election of head of village; electoral process that related to all activities that directly related to the election referring to legal and technical legislations; and electoral law enforcement, which is the enforcement of political, administrative or criminal election rules.

The framework model is simply described in the following figure:

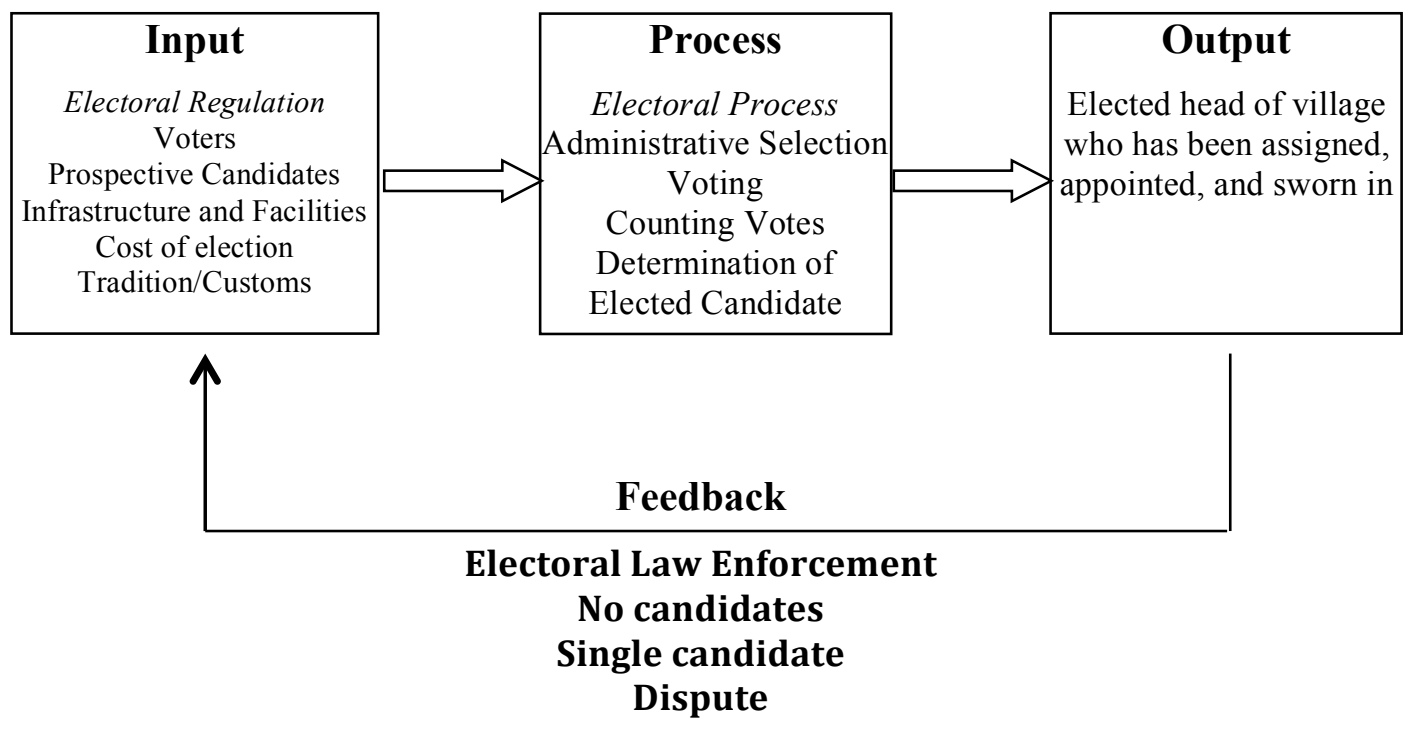

Figure 1. Model of Framework

\section{RESEARCH METHOD}

The research used qualitative approach based on the aim of the study to describe and analyze the linkage between sub-systems and the work of "cara" and "tata" in the election of head of

\footnotetext{
2 This Easton's opinion is cited by Mohtar Mas'oed and Colin Mac Andrews (ed) in their book Introduction to Comparative Political System. 1991. Yogyakarta: UGM Press. p. xii

${ }^{3}$ Sadu Wastiono in his book "Heads of Village and Their Election Dynamic". 1993. Bandung: Mekar Rahayu. p. 71

4 Sadu Wasistiono, op.cit., p.71-72 and Joko J. Prihatmoko in his book "The Direct Local Election". Yogyakarta: Pustaka Pelajar in cooperation with LP3M UWM Semarang. p. 205--206
} 
Neglasari Village in 2015. The existence of tradition in Neglasari originated from Islamic thought and Naga customs were other consideration in choosing qualitative research. According to Taylor \& Bogdan (1984), Nasution (2003), Sugiono (2005), and Irawan (2007) qualitative research will be appropriate for a research with this type of purpose and characteristics since the focus of the research is tended to disclose the meaning of facts that will be visible. As well as the linkage between sub-systems that likely gives other meanings behind the visible facts obtained in the research.

Strategy used to answer the purpose of the research was a case study since it gives space in deepening research problems; in this case, to study more on the election of head of Neglasari Village in 2015 in the perspective of system. Detail in the disclosure of typical things can be obtained using case study strategy, especially related to the cause of the linkage in the election of head of Neglasari Village.

Based on the above consideration, the relevant and appropriate data collection techniques for the research were unstructured interview, documentation and observation. Interview was conducted with village election committee 2015 related to regulation and electoral process as well as the enforcement of rules in the election of head of Neglasari Village. Interview was also conducted with the village elders (sesepuh) related to the existing tradition in Neglasari in the election of its head of village. Documentation was conducted to obtain data on policies related to the simultaneous election of head of village, stages of election and data or information on candidates of head of village, list of temporary and final voters, and so on. Observation was conducted by staying at the research location especially during campaign and voting period in order to increase the analysis on the linkage between sub-systems in the election of head of village. The research was conducted during the period of head of village election in October 2014 to March 2015.

\section{RESULT AND DISCUSSION \\ The Linkage of Input Components in the System of the Election of Head of Neglasari Village in 2015}

Regulation of head of village election in Neglasari was referred to Act No. 6, 2014 on Village, Government Regulation No. 43, 2014 on the Implementation of the Regulation of Act No. 6, 2014 on Village, Regulation of the Minister of Home Affairs No. 112, 2014 on the Election of Head of Village and Regent Regulation No. 4, 2014 on the Guidelines for the Candidacy, Election, Appointment, Inauguration and Dismissal of Head of Village in Tasikmalaya Regency. Based on those regulations, there were stages in the currently simultaneous head of village election. Act No. 6, 2014 set 3 (three) stages in the election: candidacy, voting and appointment. In addition to the regulation from the level of supra-village, there was also regulation from the village level itself related to the establishment of election committee based on the "cara" prevailed in Neglasari through village consultation.

The committee was part of preliminary stage ${ }^{5}$ and fully responsible for the election of head of village in Neglasari and it was formed through village consultation conducted by BPD (Village Consultative Body) and village government in October $3,2014^{6}$. The committee, then, compiled

\footnotetext{
5 In PP (Government Regulation) No. 43, 2014 the preliminary stage is one of (initial) stages in the election of head of village.

${ }^{6}$ Actually, provision on the formation of the committee from Tasikmalaya Regency is not yet available. The basic for the formation of committee conducted in Neglasari was referred to a "habit" that before the end period of the head of village, a committee is formed (PP No. 72, 2005 set that at least four months before the end term of the head of village, BPD processes the election; whereas, Act No. 6, 2014 set it for 10 days after the announcement of the end term). In addition, it is known from the information from the Committee
} 
initial working plan, which was socialization activity around 9 (nine) times from December 13, 2014 to January $3,2015^{7}$ located at mosques and village hall. The mosques were chosen by the committee for socialization with consideration of effectiveness and efficiency. In Neglasari, mosque is a strategic place for villagers to gather in a big crowd such as for religious activities. This activity is the daily part of Neglasari villagers. Information delivered during the socialization was mostly on the plan of head of village election and estimation of cost should be paid by the community for the election.

Based on the provision, the election of head of village in 2015 was conducted just like the previous election basing on liberal democracy tradition where head of village is directly elected by the villagers and candidate with most voters is the elected one ${ }^{8}$. Due to the provision, the availability of eligible voter data was very important. Regarding this data, the committee referred to data available during presidential election in 2014. Therefore, updating data was not difficult to do since initial data was existed. The committee only added or reduced the number of voters from each kapunuhan ${ }^{9}$ according to population data in each RT (neighborhood association). Temporarily, the list of final voters for head of village election 2015 was 4,338 people with the following detail for each kapunduhan: Kapunuhan Naga (1,632 voters), Tanjaknangsi (1,176 voters), Cikeusik (608 voters) and Sukaratu (923 voters).

In addition to voters, candidates would be the main thing in the election. It was differ from the previous elections where candidates would need "approval" from the village elders (sesepuh) ${ }^{10}$ through babadamian ${ }^{11}$, in this head of village election 2015, the committee had no difficulty to get prospective candidates. The policy of village fund set by the government gave big impact to the change in villagers' mind pattern. Before the registration for candidates, there were 4 (four) villagers who were ready to enter the election. They were Mr. Kurnia, Mr. Yaya Sunarya, Mr Jajang Hadiwijaya and Mr. Henhen Suhenri ${ }^{12}$. Of those four persons Mr. Kurnia, Mr Jajang Hadiwijaya and Mr. Henhen Suhenri had the same chance; whereas Mr. Yaya Sunarya had small chance to even surpass them since he is not native of Neglasari Village. Mr. Kurnia is the village figure and a native of Neglasari (sanaga) and former head of village for 2002-2008. Mr. Jajang Hadiwijaya is a sanaga and head of village youth organization. Mr. Henhen is the brother of kuncen (indigenous leader) of Kampung Naga. Kampung Naga is the main kampong of all kampongs that form Neglasari Village.

\footnotetext{
that there is oral statement from Salawu Head of Sub-district that allows the formation of the committee. It is also known that in Neglasari the committee is formed to avoid rashness in the election due to the uncertainty from the government or as anticipation. In addition, the work of the committee is limited to socialization to the villagers and not the main activity or stage. An official provision on election in Tasikmalaya Regency is, actually, issued in January 2, 2015. The provision is not a regional regulation as mandated by the law since it is only Regent Regulation. Based on the provision, it is known that there are 13 activities in the election of head of village. Based on the prevailing regulation, the election committee should fulfill the elements of village staffs, community institution, and village community figures. Research result shows that the Committee at Neglasari has fulfilled the elements.

${ }^{7}$ The official schedule of socialization is set by the regency government, which is January 17-20, 2015. The committee of head of village election in Neglasari has completed the activity before the provision is issued. The committee decision to start the activity since December 2014 is beneficial since the time and place of socialization could reach all areas.

${ }^{8}$ Based on PP No. 43, 2014 if more than one candidate receives the most voters, candidate elected is the one with wider range vote. The committee would translate it evenly for each kapunuhan

${ }^{9}$ Kapunuhan is an area that part of a village. In some area, kapunuhan is also called with other terms such as dusun or kedusunan

${ }^{10}$ A village figure who has big influence on Neglasari people. Generally, he is old enough and has "superiority" compared to other villagers usually in terms of religious knowledge, virtues, moral and policy (leadership).

${ }^{11}$ Babadamian is a local institution owned by Neglasari people to make decision for example to choose the leader. At first, the institution is the manifestation of village meeting at Neglasari. Etymologically, the institution is identic with the term of musyawarah (consultation), which is an activity to make decision. Further explanation can be seen in previous writing on babadamian.

${ }^{12}$ Actually, there were more people who were running for head of village; however, only four who were openly show their interest to run for the head of village.
} 
From those three candidates, Mr. Henhen was in the first position to be elected as head of village because he would get support from sesepuh and pinisepuh of Kampung Naga. All this time, in every head of village election at Neglasari, the support of sesepuh and pinisepuh of Kampung Naga has positive correlation. It means that the candidate would receive most votes and elected as head of village. Research result shows that it was related to the existence of sanaga who are the majority population at Neglasari Village (around 2/3 of population is sinaga).

Although Mr. Henhen had advantage with his status, other two candidates were sure that they would win the election. Mr. Kurnia, who was a former head of village and a public figure, was very confidence because he had high popularity than Mr. Henhen who was only known at Kampung Naga. He was also popular than Mr. Jajang because his social and economic activities were not outside Neglasari. Mr. Jajang, on the other hand, had strong belief due to his political activity with Nasional Demokrat Party that he considered as his selling point. In this case, he would gain access to local and central government. In addition, he also felt a strong bond with other sanaga.

The map of power among the candidates was changed when Mr. Sobirin, the former head of village, was also running back. The three candidates were recalculated their possibility to win the election. Mr. Jajang had smaller chance due to this event because he was in the same kapunduhan with Mr. Sobirin. As well as Mr. Kurnia, he needed to calculate Mr. Sobirin strength at Sukaratu. Although Mr. Sobirin was not a native of Sukaratu but he had fairly strong support base and comparable with Mr. Kurnia.

The same situation was faced by Mr. Henhen since he would receive less support. The support was not from kapunduhan Naga but from other kapunduhan. Regarding Kapunduhan Naga, with full support from Kuncen Naga, it was less likely that many votes would shift to Mr. Sobirin. The belief of Mr. Henhen's party was reasonable because based on the history of head of village election at Neglasari, candidate receiving support and approval from sesepuh of Kampung Naga will be elected as head of village. As explained, the majority of Neglasari people (around 2/3) was sanaga or the ancestry of Kampung Naga. With the support from sesepuh and pinisepuh of Naga, the chance for Mr. Henhen to be elected as head of village in 2015 was big because the support would be followed by urang Naga and sanaga.

Mr. Kurnia himself was initially estimated to run again for the election; however, he cancelled his candidacy. Based on information gained, it was due to his health and less support from the people including those who were from his own kapunduhan especially after the incumbent was also run for the next head of village. Mr. Kurnia was the head of BPD-32; however, he was elected due to an appointment (as a representative of Kapunduhan Sukaratu) instead of an election. ${ }^{13}$ Mr. Kurnia seemed to realize that his chance to win the election was small with the running of Mr. Sobirin for head of village. Therefore, he did not follow up his registration.

Refer to the requirement from sesepuh of Neglasari Village or Kampung Naga, the competition for head of village would only be between two candidates: Mr. Sobirin and Mr. Henhen. For Neglasari Village, "approval" from sesepuh is a tradition in the election of head of village. To get support from the villagers, both candidates should have the approval since the vote of villagers

\footnotetext{
13 Based on the information, Mr. Kurnia was elected to be the member of BPD-32 because there was a member of BPD who resigned and he was the representative of kapunduhan. Mr. Kurnia proposed himself to replace the member and to respect Mr. Kurnia, the people agreed to it and he was even elected as the head of BPD up until now.
} 
usually in line with the approval of their sesepuh. Based on information, it was known that the result of babadamian sesepuh of the village was tended toward Mr. Sobirin. It means that he was likely to gain most voters or to be chosen as the head of village ${ }^{14}$.

For the election of head of village, the committee set a budget of Rp. 31,350,000.00 (thirty one million three hundred and fifty thousand rupiah). In addition, the Government of Tasikmalaya Regency only gave fund of Rp. 15,000,000.00 (fifteen million rupiah) allocated for procurement of ballot, ballot box and other equipment and tools, honorarium for committee, and fee for the inauguration of elected head of village. Therefore, there was lack of fund of Rp. 16,350,000.00 (sixteen million three hundred and fifty thousand rupiah). This lack of fund would be charged to the village budget (APBDesa). However, in reality, the lack of fund was paid by the society itself. The amount of fund paid by the society was set by Regulation of Neglasari Village No. $03 / 2004 / \mathrm{I} / 2015$ on January 16,2015 . The amount of money paid by society was Rp. $4,000.00$ /vote that was differed to the one previously set by the committee of Rp. 7,000.00 (seven thousand rupiah). The amount was based on the number of voters of 4,338 people.

\section{The Work of Village Tradition in the Electoral Process of Head of Neglasari Village in 2015}

The electoral process of head of village was started with administrative selection of prospective candidates to be determined as candidates of head of village. This activity could be done by the committee since the number of candidates had met the requirement set by legislation, which is more than one candidate. When the four candidates had passed administrative selection, they would be stated as passing the selection by fulfilling various requirements and passing the local test conducted by the committee. The test consisted of reading and writing Koran (Al-Qur'an). The result from reading and writing the Koran test would not influence whether or not the candidates qualify for selection. The test was more to evaluate the requirement of devoted to God Almighty One. Therefore, four of them were qualified as the candidate for head of village in the next election for period of 2015-2021 and they had the same right to be chosen in the electoral process of head of village. Since the candidates were more than one, the election of head of Neglasari village could proceed to the next stage.

The first activity after the determination of candidates was campaign. Before campaign was conducted, the candidates received number through a draw conducted before the villagers on March 2, 2015. The numbers of each candidate were, respectively: Number 1: Mr. Yaya; Number 2: Mr. Jajang; Number 3: Mr. Sobirin and Number 4: Mr. Henhen.

In contrast to the campaign of other head of region candidates, campaign in Neglasari was conducted together for four candidates in one place (in panel) ${ }^{15}$. The committee gave time for each candidate to present their work program for 15 minutes. The first candidate had program that focusing on social issues. The second candidate had work program that based on

\footnotetext{
${ }^{14}$ Detail reason for the possibility can be seen in other writings on two tradition of democracy in the election of head of village in 2015.

15 The schedule of campaign follows the social and cultural condition of Neglasari Vilage where people were busy in the morning and finished their work before noon (dzuhur) around 12:00 pm; therefore, campaign time was set at 13:00 - 16:30 WIB. Formally, the committee did not arrange a schedule for campaign for each candidate either a campaign conducted by the candidates or their own campaigners. Although there were "campaigns" conducted by the candidates or their campaigners, it was an informal one and limited to small talks conducted at food stalls, mosque, ojek station, and other places where people usually gather or directly come to the villagers' houses.
} 
nationalist values. The third candidate brought religious-value based program. Whereas the program from forth candidate was based on traditional values. Based on the programs brought by all candidates, programs from the first candidate was likely to be easier to understand by the villagers. The main focus of the first candidate was in improving social field with his main program was preparing village ambulance. In addition, during the presentation, the first candidate was better prepared than other candidates.

The next stage after campaign and silent period was voting conducted on March 16, 2015. Voting was considered as the most interesting, important and principle thing in every election of head of village. It was interesting because in this stage the villagers gathered in large numbers whether they were voters or no because they would like to see the election of their leader directly. The stage was also important because various events were often occurred that could determine the fate of each candidate. In addition, this stage would be the proof for the support of villagers and the success of election and so on. Moreover, it was the main stage because it often identified with election where voting itself is one of stages in the election. Furthermore, it would be the proof whether the election was democratic or not.

In contrast to legislative and presidential election that conducted at several polling stations (TPS), head of village election was centered at one place, which was Bale Desa (Village Hall) of Neglasari Village. The committee divided Bale Desa into three parts: polling station, seating for voters and seating for candidates and their witnesses on the podium on the right side of the entrance. The polling stations (TPS) were divided into four places according to the numbers of kapunuhan at Neglasari Village: TPS Naga, Cikeusik, Sukaratu and Tanjaknangsi. The division of the TPS based on kapunuhan was started from the time the voters entering the corridor of Bale Desa.

Since the polling station was centralized the situation was overwhelmed. Since 06:00 am, many people came hoping to get the first line. Interaction among them was intense and massive since it was not only the voters who came but also teenagers and children were brought by their parents and there were also traders from outside the village. Moreover, there were also certain parties called by the people as the "players" ${ }^{16}$. They were people from outside the village who utilize the event to get profit through gambling (wager).

Voting was actually started at 07:00 am; however, since the candidate No. 2 (Mr. Jajang) had not arrived yet, the voting was pushed back. ${ }^{17}$ The candidate arrived the village hall at 09:00 am. At this time, the voting did not start immediately since the committee conducted other agendas such as greeting from the head of committee, introduction of candidates, the pledge from the candidates of head of village and the sign of letter of authority from the candidates of head of village to witnesses assigned. The voting was started at 10:30 am by the head of village candidates based on their number. As agreed, the voting was closed at 13:00 pm, an hour late from the predetermined schedule.

\footnotetext{
${ }^{16}$ The gambling practice is not only occurred at Neglasari Village but in almost all places where an election take place. It is not only occurred in Tasikmalaya also. Based on information from one of the "players" it is also often occurred in Garut, Sumedang and other areas. He knows the information since he is one of them.

${ }^{17}$ Based on information, it is know that the candidate was deliberately came late because he considered that 7:00 am was not a "good" time based on his calculation. It was also known that the candidate was one of candidates who registered as the candidates on Sunday. In the election of head of village in Neglasari and likely in other villages that still considered traditional values, "calculation" from the elders was an important thing to give better chance for them to gain more votes; therefore, the calculation was not only in terms of day and time but also the direction and the first footstep taken.
} 
Based on the recapitulation result of 4,338 voters registered, there were 3,300 voters who used their voting right or about 76.07\%. Of the numbers, the invalid ballots were $26(0.79 \%)$ and 5 was blank (0.02\%). Therefore, the number of valid ballots were 3,269 (99.06\%). The first kapunuhan calculated was Cikeusik with 455 votes in from total 620 voters $(73.39 \%)$ with invalid ballots of 6 votes. Kapunuhan Naga, from 1,644 voters, 1,302 (79.20\%) used their voting right with 1,290 valid votes, 8 invalid, and 4 blanks. The counting continued to Kapunuhan Sukaratu with 648 voters who used their right from 929 voters registered or about $68.78 \%$ with 639 valid votes, 6 invalid and 3 blanks. The last count was conducted for Kapunuhan Tanjaknangsi with 897 votes from 1.189 voters (75.44\%) with 891 valid votes and 6 invalid. From the four kapunuhan, the incumbent candidate, Mr. Sobirin, won in three kapunuhan: Tanjaknangsi, Sukaratu and Cikeusik. As estimated, Mr. Henhen won in Kapunuhan Naga with small margin to Mr. Sabirin (49,22\% : 32,87\%). Detail of votes for each candidate can be seen in the following table.

Table of Votes for Each Candidate per Voting Place (TPS) (Kapunduhan) In the Election of Head of Village of Neglasari in 2015

\begin{tabular}{|c|c|c|c|c|c|}
\hline \multirow{2}{*}{$\begin{array}{l}\text { KAPUNUH } \\
A N\end{array}$} & \multirow{2}{*}{ DESCRIPTION } & \multicolumn{4}{|c|}{ NUMBER OF CANDIDATES } \\
\hline & & 1 & 2 & 3 & 4 \\
\hline \multirow{3}{*}{ Cikeusik } & Total Votes & 50 & 83 & 263 & 53 \\
\hline & $\begin{array}{l}\text { Total Voters Who Came } \\
\text { and Valid }\end{array}$ & 449 & 449 & 449 & 449 \\
\hline & Percentage & $11,14 \%$ & $18,49 \%$ & $58,57 \%$ & $11,80 \%$ \\
\hline \multirow{3}{*}{ Naga } & Total Votes & 48 & 183 & 424 & 635 \\
\hline & $\begin{array}{l}\text { Total Voters Who Came } \\
\text { and Valid }\end{array}$ & 1.290 & 1.290 & 1.290 & 1.290 \\
\hline & Percentage & $3,72 \%$ & $14,19 \%$ & $32,87 \%$ & $49,22 \%$ \\
\hline \multirow{3}{*}{ Sukaratu } & Total Votes & 31 & 231 & 295 & 73 \\
\hline & $\begin{array}{l}\text { Total Voters Who Came } \\
\text { and Valid }\end{array}$ & 639 & 639 & 639 & 639 \\
\hline & Percentage & $4,85 \%$ & $36,15 \%$ & $46,18 \%$ & $11,42 \%$ \\
\hline \multirow{3}{*}{$\begin{array}{l}\text { Tanjak- } \\
\text { nangsi }\end{array}$} & Total Votes & 11 & 196 & 671 & 13 \\
\hline & $\begin{array}{l}\text { Total Voters Who Came } \\
\text { and Valid }\end{array}$ & 891 & 891 & 891 & 891 \\
\hline & Percentage & $1,23 \%$ & $21,99 \%$ & $75,31 \%$ & $1,46 \%$ \\
\hline \multirow{3}{*}{$\begin{array}{l}\text { NEGLA } \\
\text { SARI }\end{array}$} & Total Votes & 140 & 693 & 1.653 & 774 \\
\hline & $\begin{array}{l}\text { Total Voters Who Came } \\
\text { and Valid }\end{array}$ & 3.269 & 3.269 & 3.269 & 3.269 \\
\hline & Percentage & $4,28 \%$ & 21,20 & $\mathbf{5 0 , 5 7}$ & 23,68 \\
\hline
\end{tabular}

Source: Election Committee of Head of Neglasari Village, 2015.

Based on the result of counting presented in Table 1, Mr. Sobirin still had support or trust from the villagers since he received most votes of 1,653 or $50.57 \%$ of the total valid ballots of 3,269 . The biggest percentage of his votes came from Kapunuhan Tanjaknangsi, which is his main votes area, with votes of 671 (75.31\%). Next position was Mr. Henhen with votes of 774 $(23.68 \%), M r$. Jajang with 693 votes $(21.20 \%)$ and the last was Mr. Yaya with only 140 votes or $4.28 \%$.

The winning of Mr. Sobirin in the election of head of village was obvious when the calculation of ballots in Kapunuhan Naga was finished. The result was 424 votes (32.87\%) with difference 
of 211 votes from Mr. Henhen. Actually, Kapunuhan Naga was estimated as the main votes for Mr. Henhen since he was the brother of the traditional leader of Kampung Naga. Therefore, it was predicted that he would get absolute winning in the area over Mr. Sobirin. However, the result was different since there were also voters who chose Mr. Jajang with 183 votes (14.19\%) and Mr. Yaya with 48 votes (3.72\%).

Based on the counting of two kapunuhan (Cikeusik and Naga), Mr. Henhen was temporarily surpassed Mr. Sobirin; however, Mr. Sobirin won due to the votes from Kapunuhan Naga that significantly indicated that the incumbent would once again lead the Neglasari Village since in the two other Kapunuhan Mr. Henhen had no strong support. The supporters of Mr. Sobirin were increasingly believed when the calculation for Kapunuhan Sukaratu was finished since it also won by their candidate in a significant difference from $\mathrm{Mr}$. Henhen with comparison of 295 votes (46.18\%) to 73 votes (11.42\%). Therefore, temporarily, Mr. Sobirin surpassed Mr. Henhen with difference of 221 votes $(982-761)$. With only one counting left for Tanjaknangsi, the winning of Mr. Sobirin was unstoppable by Mr. Henhen since the kapunuhan was the base for Mr. Sobirin. At the end of the counting, it showed that Mr. Sobirin had 671 votes (75.31\%); whereas, Mr. Henhen with 13 votes (1.46\%). The result of Mr. Henhen was far from votes obtained by Mr. Jajang with 196 votes (21.99\%). Mr. Henhen only 2 votes differ from Mr. Yaya (11 votes / 1.23\%). In total, as indicated in Table, Mr. Sobirin had 1,653 votes (50,57\%) and Mr. Henhen had 774 votes (23.68\%).

\section{The Determination of Elected Head of Village and Settlement of Post-Election Dispute}

One day after the Election Day on March 17, 2015 the committee decided the Candidate No. 3, Mr. Sobirin, as the elected head of village for 2015 - 2021. Then, the committee reported to BPD Neglasari with a copy to Head of Salawu Sub-district. BPD submitted the report of elected candidate and suggested validation to Regent of Tasikmalaya through Head of Salawu Subdistrict.

Refer to the aspect stated by Sadu Wasistiono (1993) which is acceptability, capability, and comfortability, the winning of candidate No. 3 (Mr. Sobirin) and the loss of other three candidates is accepted. In the aspect of capability, although it was not absolutely better, he was experienced as head of village and he was considered as succeed in giving value added for the villagers' acknowledgement in his administrative and managerial ability. On the contrary, the failure in actuating Youth Association gave less appreciation from the villagers to candidate No. 2.

For candidate No. 1, it was not his ability that being questioned by the people. Actually, his background was superior compare to other candidates. However, the villagers could not directly appraise his ability since during the 2000s the villagers did not see his involvement in the village. Similar opinion prevailed for candidate no. 4. Although he was the deputy of kuncen it was unlikely that he had better ability in administrative and management than candidate no. 3 because similar to other candidates he was rarely to be involved in village activities.

Activities of candidates in village government and in the society were apparently the key for the villagers to appraise the capability of the candidates. Actually based on other capability aspects such as level of education, candidate No. 3 and 4 had graduated from senior high school and other two candidates had level of education of junior high school. Regarding work experience, candidate No. 1 was better than other candidates including candidate No.3 who was toys peddler before becoming head of village in 2008 - 2014. However, candidate No. 3 was an active youth figure especially in sport since he had a background of education at School 
for Physical Teacher. He had more activities in the society after becoming head of village. He was active in various religious activities conducted in all mosques in Neglasari village. It was these activities that become the key for the winning of candidate No. 3 in three kapunuhan at Neglasari Village in addition to Kapunuhan Naga.

Work background of candidate No. 2 was considered as better than those of candidate No. 3 . According to his statement he was working in contractor field and as the second hand of Mr. Eka Santosa, former Chief of DPRD of West Java. As well as candidate No. 4, he had better economic life than candidate No. 3 although both of them were an entrepreneur. Once again, the activities of candidate No. 3 in the last six years as head of village gave value added during the election since he was always active in the society's life. Therefore, his popularity was better than other candidates.

The second aspect is comfortability; however, the aspect was implemented differently than those conducted by Wasistiono (1993). In his explanation, comfortability is related to the compatibility of head of village candidate with the desire and need of the supra-village government during New Orde Era. In the case of current head of Neglasari village election, comfotability was used by looking at the suitability of head of village candidate with the view and appraisal of village figures.

There were two village figures at Neglasari Village: sesepuh and community figures. Based on social stratification, sesepuh had higher strata than community figures. A sesepuh is certainly a community figure; a community figure, on the contrary, is not always a sesepuh. It was likely that there were other requirements should be met by a community figure to be called as sesepuh. In turn, sesepuh has bigger influence than society figure. Therefore, the result of candidate having approval from the sesepuh will be different than those who had support from society figure.

Candidate No. 1 claimed that his candidacy was supported by society figure and his surrounding villagers. The problem was that the society figure he mentioned was not a village sesepuh. The figure was likely not the village figure or a figure in its kapunduhan but he was a figure in his kampong (hamlet). It can be seen from other candidates who came from the same kapunduhan, Candidate No. 4, who was obviously supported by some kasepuhan Naga including its own kuncen since this candidate was urang (native) of Kampung Naga; whereas, candidate No. 1 was a migrant. Therefore, it was clear that society figure mentioned by candidate No. 1 was neither sesepuh of Kampung Naga nor village sesepuh. On the other hand, candidate No. 4 was indeed gained approval from sesepuh but only from sesepuh Naga and not all village sesepuh. His popularity and capability were not enough to get approval from sesepuh in other three kapunuhan although in majority the population was sanaga.

Similar problem was faced by candidate No. 2. His claim on getting support from community figure and the villagers might be correct but it is back to the construction of village community figure as explained. The community figure who gave support to him was not sesepuh; therefore it had less influenced to the villagers' vote. Similar to candidate No. 1 and 4, their popularity and capability were unable to bring approval from village sesepuh for them. Thus, they gained fewer votes than candidate No. 3 including in Cikeusik and Sukaratu that were considered as neutral areas based on the domicile of the candidates. 
As previously explained, the candidacy of candidate No. 3, Mr. Sobirin, was unexpected because there were no news on his candidacy until before the registration of perspective candidate. Mr. Sobirin was running again for the election because he was supported by the villagers and community figures and especially, he got approval from village sesepuh. Due to this approval from village sesepuh, his popularity and capability was increasingly meaningful for the villagers of Neglasari, in general. In turn, during the election he was outvoted other candidates.

From the above explanation, it can be said that based on acceptability aspect, candidate No. 3 was above other candidates. This achievement was related to other three aspects that he had that definitely better than other candidates. Therefore, it was not surprising that candidate No. 3 had the most votes in the election of head of village.

The interesting thing in the current election of head of village in Neglasari was the split of votes in TPS Naga indicating that sesepuh and pinisepuh in Kapunduhan Naga were no longer solid. This faded solidarity among sesepuh and pinisepuh was due to different opinion in appraising the capability or competency of the candidates. For some of pinisepuh, candidate No. 3 (Mr. Sobirin) had better capability and competency than other candidates from their kampong.

The opinion of some pinisepuh was based on the leadership of Mr. Sobirin during his tenure as head of village in Neglasari. Mr. Sobirin was considered to have respect on the existence of Kampung Naga indicated through his activities where he often visited sesepuh and pinisepuh such as when he wanted to make decision for the interest of Naga or Neglasari (babadamian). In addition, Mr. Sobirin was a sanaga and even his grandfather and great grandfather were respected pinisepuh of Naga at their time. Therefore, candidate No. 3 had good comfortability at Kapunuhan Naga.

The votes gained by candidate No. 2 was considered as sufficient since the candidate was also a sanaga and had enough vote basis among the sanaga. However, due to the less approval from sesepuh and pinisepuh caused by his less capability or competency and popularity, his votes could not outperform candidate No. 4 or even No. 3. The less comfortability of the candidate was also due to the conflict approach he built with Kampung Naga previously. Therefore, he should be grateful since there were villagers who were willing to give their vote to him.

Candidate No. 1 gained only $3.72 \%$ votes in the election. This number was considered as pathetic. However, based on his social and cultural background, this minimum votes or support from the villagers of Kapunduhan Naga was predictable. Nevertheless, the vote he gained was certainly an achievement in the middle of competition with three candidates who have familial link with Naga yet there were people who gave support to him.

The election of head of village in Neglasari was running smoothly and democratic. Every stage required in electoral regulation was well performed including the formation of committee. However, after the determination of the elected head of village, there was dissatisfaction from the loser, which was candidate No. 4. The dissatisfaction did not show in form of an open protest as in the election of district head so it was known to the public; instead, the dissatisfaction was submitted informally by candidate No. 4 . This way was chosen by candidate No. 4 to submit his dissatisfaction due to his feeling as a family and the values of togetherness. The submitted dissatisfaction was not due to his defeat but more to the number of vote he gained in TPS Naga that less than 50\% whereas he estimated that his vote would be $70-80 \%$ in this polling station. However, even if the candidate could gain $80 \%$ of votes in TPS Naga (as his claimed) mathematically he would never be able to beat the vote gained by candidate No. 3 . 
The number of valid ballots in TPS Naga was 1,290 means that candidate No. 4 would gain at least 1.032 votes $(80 \%$ of 1,290$)$. If it added with the number of votes he gained from the three other polling stations the number would be 1,171. Whereas, if the vote of candidate No. 4 reduced by the vote he gained in TPS Naga (with impossible assumption that he gained no votes at all) his total vote would be 1,229. Therefore, the vote of candidate No. 3 was still bigger than those of candidate No. 4.

For the party of candidate No. 4, especially the kuncen, although their candidate won in TPS Naga, it still meant a loss since the vote in Naga was not solid. The vote that not solid in Kapunduhan Naga was an indication that the komara (authority) of kuncen as the highest leader for urang Naga and sanaga has faded. The clear direction (signal) of support from kuncen to candidate No. 4 apparently was not obeyed and followed by all villagers of Kapunduhan Naga, including in Kampung Naga itself. Whereas, during the election kuncen brought in a mass organization - based on information he was the leader of the organization — called Indonesian Grassroots Movement (Gerakan Masyarakat Bawah Indonesia, GMBI). The presence of GMBI was allegedly to give "pressure" to the villagers and to show the power of kuncen. However, the strategy was failed to gain support from Neglasari people as a whole. This was the reason for the dissatisfaction of candidate No. 4, especially kuncen.

Another reason for the disappointment of the kuncen was that the candidate is his brother. The reality, however, showed that some urang Naga and sanaga elected other candidates that differ than those of kuncen, especially candidate No. 3. Based on leadership theory when the order of leaders is not followed by their followers it means that their leadership is started to less influential; whereas, the obedience of followers toward the leader is the main thing in a leadership especially in indigenous community. The condition was indirectly indicated that there was another leader whom his/her leadership was more acknowledged by some urang Naga and sanaga (the cause for the faded leadership of kuncen can be seen in next article). The leader, in this case, was Punuh Naga. In the election of head of village, punuh Naga became the election committee and considered as not neutral. With the entry of punuh as the committee, the representative of village staffs in the committee was many. The candidate No. 4 thought that the existence of village staffs in the committee was the supporter of candidate No. 3 since the candidate was an incumbent. Therefore, when punuh became the member of the committee the support for candidate No. 3 was bigger.

The party from Candidate No. 4 then asked for re-election and replacement of the committee. The presence of punuh in the committee was considered as against the rule since punuh was part of village government and the village government already had three representatives in the committee. Based on committee data, there were indeed 7 (seven) representatives of village staffs. Whereas, community institutions were represented by Mr. Harso Warsoyo and Mr. Abdul Chobir (MUI) and society figures were represented by Mr. Alit Senjaya (Youth Figure) and Mr. Sarip (LPMD/ Rural Community Empowerment Agency).

However, based on information, all heads of kapunduhan (Naga, Tanjaknangsi, Cikeusik, and Sukaratu) did not represent village staffs but the element of community figure. Empirically, the four of them were community figures but at that time they were all head of kapunduhan. In legislation, head of kapunduhan (hamlet) is the element of village government incorporated in village staffs along with secretary and technical implementing as regional implementing (Article 25 and 48 Act No. 6, 201; Article 1 and 61 Government Regulation No. 43). 
Theoretically, community figure is known as elite term. Elite term basically refers to a group of people in a society, traditional or modern. This group of people, in the end, becomes the main group having larger power than other groups. According to Sanderson (1993) the difference in power ownership shows social stratification due to the existence of group whose members have power, prestige and privilege.

These elite are also explained by Vilfredo Pareto who divides elite in two classes: the governing elite and non-governing elite (Bottomore, 2006). Bottomore divides these two classes of elite in terms of the level of involvement in the governance. Based on this division non-governing elite does not mean have no role in the government. Anyone who is in the category still pays attention on government and development but has no certain position in the government. These elite still work for community development outside the governance structure.

From the above explanation, theoretically, head of hamlet can be categorized as community figure. Therefore, their assignment in the committee was correct since their position made them part of governing elite. As well as normatively, the Election Committee of head of Neglasari village did not against the prevailing rule which is Regulation of Regent No. 4, 2015. The regulation did not clearly and firmly set on community figure. It means that the entry of head of hamlet in the committee of head of village election was justifiable.

The dissatisfaction of candidate No. 4 was discontinued. Resolution for the dispute was conducted through babadamian that involved sesepuh, pini sepuh, community figure, village government, BPD and the committee itself and it conducted in Kampung Naga. A dispute regarding the committee could be resolved since the committee was chosen through consultation among villagers on October 3, 2014 and re-confirmed on January 16, 2015. Reelection was unnecessary since mathematically it would not change the position of the candidates since the vote difference between candidate 4 and candidate 3 was far as explained above. Therefore, it can be stated that electoral law enforcement was well performed. Finally, Mr. Sobirin who has been appointed by the committee as the Elected Head of Village was inaugurated by Regent of Tasikmalaya along with other 67 head of villages on Monday, April 13, 2015 at Gedung Pendopo Kabupaten.

\section{CONCLUSION AND SUGGESTION}

In the perspective of system, the election of head of village is part (sub) of a bigger system and in this case, it is part of village government system. However, the election of head of village can also be seen as a system since the existence of various sub systems that build and move it that will influence the village government system. Sub systems in the election of head of village are: election regulation, tradition, villagers as voters and the elected (candidates), cost of election, activities that are part of the electoral process, the appointment of elected candidate and resolution for post-election dispute.

In the election of head of Neglasari Village in 2015, every sub system in the election was well performed. It can be seen from the election that in accordance with the regulation predetermined by the state. The election of head of village in Neglasari was interesting since there was tradition that still existed and had strong influence in building the direction of democracy to be developed in Neglasari. The tradition was in form of "approval" that should be gained by the candidates in order to get broad support from the villagers in the election so they could be chosen as the leader in Neglasari. The tradition is obtained through a local institution called babadamian that is still working up until now and is running by the village elders (sesepuh). Through this institution also, a dispute occurred after the election could be solved. The dispute 
did not extend and acute that could create a conflict which required settlement by government from supra-village level (Salawu Sub-district and Tasikmalaya Regency).

In the perspective of system, the existence of tradition in the election of head of village in Neglasari gives certain color. Regulation set by the state is increasingly meaningful when the principle and the objective of the election, which is to elect the right people in the right place, can be achieved. The work of village tradition in the election, especially during the election of nomination of candidates, is the determinant for the achievement of the objective. Therefore, it will be better if the state gives broad opportunity for village tradition to work together with regulation set by the state.

\section{References}

Antlöv, Hans. 2003. Negara Dalam Desa. Patronase Kepemimpinan Lokal. Yogyakarta: Lapera

Boeke, J.H. 1971. Batas-batas Dari Masyarakat Pedesaan Indonesia. (terjemahan LIPI kerjasama dengan KITLV) Jakarta: Bhratara

Steven J Taylor, Steven J and Bogdan, Robert. 1984. Introduction to Qualitative Research Methods: the Search for Meaning. Wiley \& Sons. Inc, New York

Hatta, Moh. 2009. Demokrasi Kita. Pikiran-pikiran Tentang Demokrasi dan Kedaulatan Rakyat. Bandung: Sega Arsy

Irawan, Prasetya. 2006. Penelitian Kualitatif dan Kuantitatif Untuk Ilmu-ilmu Sosial. Jakarta: Departemen Ilmu Administrasi Universitas Indonesia

Kartohadikoesoemo, Soetardjo. 1984. Desa. Jakarta: PN Balai Pustaka

Mas'oed, Mortar dan Colin Mac Andrews (ed). 1991. Pengantar Perbandingan Sistem Politik. Yogyakarta: UGM Press

Nasution, S. 1988. Metode Penelitian Naturalistik Kualitatif. Bandung: Tarsito

Pemerintah Daerah Kabupaten Tasikmalaya. Peraturan Bupati No. 4 Tahun 2014 Tentang Pedoman Pencalonan, Pemilihan, Pengangkatan, Pelantikan, dan Pemberhentian Kepala Desa Di Kabupaten Tasikmalaya

Poerbopranoto, Koentjoro. 1978. Sistem Pemerintahan Demokrasi. Bandung: PT Eresco

Republik Indonesia. Undang-undang Nomor 6 Tahun 2014 Tentang Desa

Peraturan Pemerintah No. 43 Tahun 2014 tentang Peraturan Pelaksana UU No. 6 Tahun 2014

Tentang Desa

Peraturan Menteri Dalam Negeri No. 112 Tahun 2014 tentang Pemilihan Kepala Desa

Sugiono. 2005. Memahami Penelitian Kualitatif. Bandung: Alfabeta

Tjiptoherijanto, Priyono dan Priyono, Yumiko M. 1983. Demokrasi di Pedesaan Jawa. Jakarta: Sinar Harapan

Wasistiono, Sadu. 1993. Kepala Desa dan Dinamika Pemilihannya. Bandung: Mekar Rahayu

Wignjodipoero, Soerojo. 1982. Pengantar dan Asas-asas Hukum Adat. Jakarta: CV Haji Masagung 